Праці НТШ Медичні науки 2021, Том 64, № 1

ISSN 2708-8634 (print) www.mspsss.org.ua
Proc Shevchenko Sci Soc Med Sci 2021, Vol. 64, 1

www.mspsss.org.ua ISSN 2708-8642 (online)

\section{Open 2 access}

DOI: $10.25040 /$ ntsh2021.01.03

\section{For correspondence:}

69, Pekarska str., Lviv, Ukraine, 79010

E-пошта: tel.ulyana@gmail.com

Received: May, 10, 2021

Accepted: May, 29, 2021

Published online: June, 29, 2021

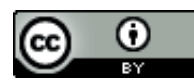

C) Ulyana Telishevska,

\section{ORCID IDs}

Ulyana Telishevska

https://orcid.org/0000-0003-4395-160X

Disclosures. Author states that there is no conflict of interest

Funding. This review did not require funding.

Ethical approval: Not required for this review.

\title{
Advances in science editing and communication (part 2)
}

Ulyana Telishevska

Prosthetic Dentistry Department Danylo Halytsky Lviv National Medical University, Lviv, Ukraine

During the first half of 2021, 6 more webinars took place online, continuing a series of lectures and workshops for scientists on writing quality of scientific articles. These events were held with the support of Danylo Halytsky Lviv National Medical University, the Shevchenko Scientific Society, the Western Scientific Centre of the National Academy of Sciences of Ukraine, the Ministry of Education and Science of Ukraine and the Council of Scientific Editors of Ukraine.

The participants had the opportunity to view online broadcasts and recordings of the events at «Proceedings of the Shevchenko Scientific Society. Medical Sciences» journal's Facebook page and on YouTube channel (https:// www. youtube.com/channel/UC4OL7KIZ5UU4hrMj_--yqHw). Each registered participant received a certificate with a certain number of points of continuous professional development.

Traditionally, webinars were held in English; invited speakers included Ukrainian and foreign fellow scientists from Great Britain, Croatia, USA, Iran and India.

Keywords: scientific writing, Scopus and Web of Science databases, publication ethics, Scientific Editors' Associations, academic integrity, periodicals as a topic, predatory journals.

During the first half of 2021, 6 more webinars took place online, continuing a series of lectures and workshops for scientists on writing quality of scientific articles. These events were held with the support of Danylo Halytsky Lviv National Medical University, the Shevchenko Scientific Society, the Western Scientific Centre of the National Academy of Sciences of Ukraine, the Ministry of Education and Science of Ukraine and the Council of Scientific Editors of Ukraine.

The participants had the opportunity to view online broadcasts and recordings of the events at «Proceedings of the Shevchenko Scientific Society. Medical Sciences» journal's Facebook page and on YouTube channel (https://www.youtube. com/channel/UC40L7KIZ5UU4hrMj_--yqHw). Each registered participant received a certificate with a certain number of points of continuous professional development. Events were moderated by Olena Zimba, Associate Professor of the Department of Internal Medicine No. 2 of Danylo Halytsky Lviv National Medical University.

Lectures and master classes were aimed at acquiring the skills of analyzing scientometric databases and writing and drafting scientific articles in English.

Traditionally, webinars were held in English; invited speakers included Ukrainian and foreign fellow scientists from Great Britain, Croatia, USA, Iran and India.

\section{Armen Gasparyan, MD, PhD, FESC} http://orcid.org/0000-0001-8749-6018 https://www.scopus.com/authid/detail.uri? authorId $=56207203100$ 


\title{
Здобутки в сфері наукового редагування та комунікацій (частина 2)
}

\author{
Уляна Телішевська \\ Кафедра ортопедичної стоматології Львівського \\ національного медичного університету імені \\ Данила Галицького, м. Львів, Україна
}

Протягом першого півріччя 2021 року відбулося ще 6 вебінарів, які стали продовженням циклу лекцій та майстер-класів для науковців щодо написання якісних наукових статей. Події відбулися за підтримки Львівського національного медичного університету імені Данила Галицького, Наукового товариства імені Шевченка, Західного наукового центру НАН України, Лікарської комісії Наукового товариства імені Шевченка та ГО «Рада наукових редакторів України».

Зареєстровані учасники мали змогу переглядати онлайн трансляції подій та їх запис на сторінці журналу «Proceedings of the Shevchenko Scientific Society. Medical Sciences» y Face-

book та на каналі Youtube (https://www.youtube.com/channel/UC40L7KIZ5UU4hrMj_--yqHw), а також отримати сертифікат із зазначенням певної кількості балів безперервного професійного розвитку.

Вже традиційно, вебінари проводилися англійською мовою, серед запрошених спікерів українські та іноземні колеги-науковці з Великої Британії та Індії.

Ключові слова: наукові журнали, наукометричні бази Scopus та Web of Science, професійні організації, етика наукової публікації, академічна доброченість, хижацькі журнали.

Протягом першого півріччя 2021 року відбулося ще 6 вебінарів, які стали продовженням циклу лекцій та майстер-класів для науковців щодо написання якісних наукових статей. Події відбулися за підтримки Львівського національного медичного університету імені Данила Галицького, Наукового товариства імені Шевченка, Західного наукового центру НАН України, Лікарської комісії Наукового товариства імені Шевченка та ГО «Рада наукових редакторів України».

Зареєстровані учасники мали змогу переглядати онлайн трансляції подій та їх запис на сторінці журналу «Proceedings of the Shevchenko Scientific Society. Medical Sciences» у Facebook та на каналі Youtube (https://www.youtube.com/channel/ UC40L7KIZ5UU4hrMj_--yqHw), а також от- римати сертифікат із зазначенням певної кількості балів безперервного професійного розвитку. Модератором подій є Олена Зімба, доцент кафедри внутрішньої медицини №2 Львівського національного медичного університету імені Данила Галицького.

Метою лекцій та майстер-класів $€$ набуття навиків аналізу наукометричних баз даних та написання і оформлення наукових статей англійською мовою.

Вже традиційно, вебінари проводилися англійською мовою, серед запрошених спікерів українські та іноземні колеги-науковці з Великої Британії, Хорватії, США, Індії та Ірану:

Armen Gasparyan, MD, PhD, FESC http://orcid.org/0000-0001-8749-6018 
Праці НТШ Медичні науки

2021, Том 64, № 1 ISSN 2708-8634 (print)

Звіт про нараду

Associate Professor of Medicine; Department of Research \& Development, Dudley Group NHS Foundation Trust, Teaching Trust of the University of Birmingham, Dudley, UK; Expert reviewer of Scopus journal applications; Member, World Association of Medical Editors; Former Council Member of European Association of Science Editors and Former Chief Editor of European Science Editing journal.

\section{Jeffrey Beall}

https://orcid.org/0000-0001-9012-5330

A librarian and library scientist from Denver, Colorado best known for coining the «predatory open access publishing» term and for creating Beall's list, a blacklist of potentially predatory open-access publishers and standalone journals. Has a Bachelor degree in Spanish (1982) and a MA in English (1987) and an MSc in library science (1990). Was awarded tenure by the University of Colorado Denver in 2012 and retired in 2017. The same year his blacklist became defunct. Published a number of articles, including two in Nature, harshly criticizing predatory open access and strongly recommending upgrading journal indexing criteria.

\section{Durga Prasanna Misra, MD, MRCP (UK), FRCP (Edinburgh)}

https://orcid.org/0000-0002-5035-7396

Associate Clinical Editor, Journal of the Royal College of Physicians of Edinburgh; Assistant Professor of Clinical Immunology and Rheumatology, SGPGIMS, Lucknow, India

\section{Latika Gupta, MD}

https://scholar.google.co.in/citations?user $=1$ m4IYREAAAAJ\&hl=en

Assistant Professor of Clinical Immunology and Rheumatology, SGPGIMS, Lucknow, India; Associate Editor at International Journal of Rheumatic Diseases, Social Media Editor at the Journal of Clinical Rheumatology and Indian Journal of Rheumatology.

\section{Prof Mohammad Abdollahi}

http://pharmacyen.tums.ac.ir/en/page/ 19459/About

https://orcid.org/0000-0003-0123-1209

https://www.scopus.com/authid/detail. uri?authorId $=57200537974$
Proc Shevchenko Sci Soc Med Sci www.mspsss.org.ua ISSN 2708-8642 (online) 2021, Vol. 64,

Editor-in-Chief of DARU Journal of Pharmaceutical Sciences (Springer Nature). Listed among top scientists by Clarivate Analytics. According to Scopus, the current $\mathrm{H}$-index and total citations of MA are 78 and more than 25000. He was the EiC Iranian Journal of Medical Hypotheses \& Ideas. A Council Member of the Committee on Publication Ethics (COPE; 2013-2017).

Acquired a PharmD in 1988 from the University of Tehran and then obtained his $\mathrm{PhD}$ degree in Pharmacology and Toxicology in 1994 from Tehran University of Medical Sciences. Passed training in Mechanistic and Clinical Toxicopharmacology at the University of Toronto in 2001. Involved in establishing the Pharmaceutical Sciences Research Center in Tehran as the Vice-Chair and Manager of the Ethics Board since 2003. Chaired the Central Library of Tehran University of Medical Sciences (2004-2006).

\section{Taraneh Mousavi}

https://orcid.org/0000-0003-1976-6789

President of Iranian Pharmaceutical Students' Association (IPhSA), Tehran local public health committee. A fourth-year pharmacy student at Tehran University of Medical Sciences (TUMS) who was admitted in 2016 and will acquire PharmD by 2022. Recently joined the Toxicology and Diseases Group (TDG), a member of The TUMS preclinical Core Facility (TPCF), The Institute of Pharmaceutical Sciences (TIPS), Society of Toxicology (SOT), International Society for Pharmacoeconomic and Outcomes Research (ISPOR) and International Pharmaceutical Students' Federation (IphSA).

\section{Vitalina Tyshchenko}

Linguist (EFL certificate in English, German), scientific researcher at the Department for Processing Scientific and Technical Information at Kryvyi Rih National University. Translator of scientific journals of Kryvyi Rih National University.

\section{Srećko Gajović}

https://orcid.org/0000-0001-8668-5239

Professor of Histology and Embryology at the University of Zagreb School of Medicine, and Head of the same Department. A former 
https://www.scopus.com/authid/detail.uri?authorId $=56207203100$

Associate Professor of Medicine; Department of Research \& Development, Dudley Group NHS Foundation Trust, Teaching Trust of the University of Birmingham, Dudley, UK; Expert reviewer of Scopus journal applications; Member, World Association of Medical Editors; Past Council Member of European Association of Science Editors and Past Chief Editor of European Science Editing journal.

\section{Jeffrey Beall}

https://orcid.org/0000-0001-9012-5330

A librarian and library scientist from Denver, Colorado best known for coining the «predatory open access publishing» term and for creating Beall's list, a blacklist of potentially predatory open-access publishers and standalone journals. Has a Bachelor degree in Spanish (1982) and a MA in English (1987) and an MSc in library science (1990). Was awarded tenure by the University of Colorado Denver in 2012 and retired in 2017. The same year his blacklist became defunct. Published a number of articles, including two in Nature, harshly criticizing predatory open access and strongly recommending to upgrade journal indexing criteria.

\section{Durga Prasanna Misra, MD, MRCP (UK), FRCP (Edinburgh)}

https://orcid.org/0000-0002-5035-7396

Associate Clinical Editor, Journal of the Royal College of Physicians of Edinburgh; Assistant Professor of Clinical Immunology and Rheumatology, SGPGIMS, Lucknow, India

\section{Latika Gupta, MD}

https://scholar.google.co.in/citations?user $=1 \mathrm{~m} 4 \mid \mathrm{YREAAAAJ} \& \mathrm{hl}=\mathrm{en}$

Assistant Professor of Clinical Immunology and Rheumatology, SGPGIMS, Lucknow, India; Associate Editor at International Journal of Rheumatic Diseases, Social Media Editor at the Journal of Clinical Rheumatology and Indian Journal of Rheumatology.

\section{Prof Mohammad Abdollahi}

http: / / pharmacyen.tums.ac.ir/en/ page/19459/About https://orcid.org/0000-0003-0123-1209

https://www.scopus.com/authid/detail. uri?authorId $=57200537974$

Editor-in-Chief of DARU Journal of Pharmaceutical Sciences (Springer Nature). Listed among top scientists by Clarivate Analytics. According to Scopus, the current $\mathrm{H}$-index and total citations of MA are 78 and more than 25000. He was the EiC Iranian Journal of Medical Hypotheses \& Ideas. A Council Member of the Committee on Publication Ethics (COPE; 2013-2017).

Acquired a PharmD in 1988 from University of Tehran and then got his PhD degree in Pharmacology and Toxicology in 1994 from Tehran University of Medical Sciences. Passed training in Mechanistic and Clinical Toxicopharmacology at University of Toronto in 2001. Involved in establishing the Pharmaceutical Sciences Research Center in Tehran as the Vice-Chair and Manager of the Ethics Board since 2003. Chaired the Central Library of Tehran University of Medical Sciences (2004-2006).

\section{Taraneh Mousavi}

https://orcid.org/0000-0003-1976-6789

President of Iranian Pharmaceutical Students' Association (IPhSA), Tehran local public health committee. A forth-year pharmacy student at Tehran University of Medical Sciences (TUMS) who admitted in 2016 and will acquire PharmD by 2022. Recently joined the Toxicology and Diseases Group (TDG), a member of The TUMS preclinical Core Facility (TPCF), The Institute of Pharmaceutical Sciences (TIPS), Society of Toxicology(SOT), International Society for Pharmacoeconomic and Outcomes Research (ISPOR) and International Pharmaceutical Students' Federation (IphSA).

\section{Віталіна Тищенко}

Лінгвіст (англійська-сертифікат EFL, німецька мови), науковий співробітник відділу обробки науково-технічної інформації Криворізького національного університету. Перекладач наукових журналів Криворізького національного університету.

\section{Srećko Gajović}

https://orcid.org/0000-0001-8668-5239

Professor of Histology and Embryology at the University of Zagreb School of Medicine, 
Editor-in-Chief of Croatian Medical Journal $(\mathrm{CMJ})$, the flagship general medical journal in Europe. Upgraded the CMJ editorial policies, launched Science Communication and Knowledge Landscapes sections and expanded the influence of this Journal in Ukraine and elsewhere in Eastern Europe and Central Asia.

During webinars, scientists learned how to build sentences, paragraphs and sections of scientific articles in English grammatically correctly, reviewed typical linguistic mistakes in scientific articles and saw how to search for English for scientists on social media.

Speakers taught researchers and future researchers to conduct bibliometric analysis and use Altmetrics tools for scientific papers through international bibliographic databases, cites examples of journal metrics search and analysis based on Scopus and Web of Science. In addition, during webinars, listeners could learn the peculiarities of ORCID and Publons profiles, anti-plagiarism policies in the indexed scientific journals, while identification and avoiding predatory journals has become an especially topical issue.
Colleagues from India and Iran spoke of the free access and use of social media platforms for distributing scientific content.

After each webinar, participants could ask questions and join active discussion in English.

\section{A list of webinars with their dates:}

- January 5, 2021, «English language editing in scholarly articles. Tips for researchers and editors»

- January 18, 2021. «Bibliometric and Altmetric analyses for researchers and journal editors»

- March 24, 2021. «Elements of Success in Science Writing and Editing»

- April 13, 2021. «Visibility and Integrity of Scholarly Publications in the Time of the COVID-19 Pandemic»

- April 28, 2021, «Effective Search Strategies for Authors and Journal Editors»

- May 20, 2021, «Open Access and Social Media Platforms for Researchers and Editors»

The organization committee intends to continue the tradition of holding webinars and masterclasses on the above topic in the second half of 2021. 
and Head of the same Department. A former Editor-in-Chief of Croatian Medical Journal $(\mathrm{CMJ})$, the flagship general medical journal in Europe. Upgraded the CMJ editorial policies, launched Science Communication and Knowledge Landscapes sections, and expanded the influence of this Journal in Ukraine and elsewhere in Eastern Europe and Central Asia.

На вебінарах науковці дізналися як граматично коректно оформляти речення, параграфи та розділи наукової статті англійською мовою, розглянули типові лінгвістичні помилки у наукових статтях, а також побачили, як шукати англійську мову для науковців у соціальних мережах.

Спікери навчали науковців та майбутніх науковців як проводити бібліометричний аналіз та використовувати інструменти альтметрікс для наукових робіт через міжнародні бібліографічні бази даних, наводили приклади пошуку та аналізу журнальних метрик на основі Scopus та Web of Science. Також протягом вебінарів слухачі ознайомилися з особливостями профілів ORCID та Publons, антиплагіатною політикою в індексованих наукових журналах та особливо актуальною темою розпізнавання та уникнення хижацьких журналів.

Колеги з Індії та Ірану розкрили тему відкритого доступу та використання соціальних мереж для розповсюдження наукового контенту.

Після завершення кожного вебінару учасники могли задавати запитання та долучатися до активної дискусії також англійською мовою.

\section{Перелік вебінарів 3 датами проведення:}

- 5 січня 2021 року «English language editing in scholarly articles. Tips for researchers and editors» (Як навчитися писати наукові статті англійською мовою: поради авторам)

- 18 січня 2021 року «Bibliometric and altmetric analyses for researchers and journal editors» («Як застосувати інструменти альтметрікс та провести бібліометричний аналіз у дисертаційній роботі: поради PhD студентам»)

- 24 березня 2021 року «Elements of Success in Science Writing and Editing» (Ключові елементи успішної наукової публікації: майстер-клас для авторів та редакторів журналів)

- 13 квітня 2021 року «Visibility and Integrity of Scholarly Publications in the Time of the COVID-19 Pandemic» (Видимість та доброчесність наукових публікацій у часи пандемії COVID-19)

- 28 квітня 2021 року «Effective Search Strategies for Authors and Journal Editors» (Ефективна стратегія пошуку наукової інформації для авторів та редакторів журналів)

- 20 травня 2021 року «Open Access and Social Media Platforms for Researchers and Editors» (Відкритий доступ та соціальні мережі для науковців, авторів та редакторів).

У другій половині 2021 року оргкомітет планує продовжувати традицію проведення вебінарів та майстер-класів на вищезгадану тематику. 